\title{
Escaping the oligotrophic gyre? The year-round movements, foraging behaviour and habitat preferences of Murphy's petrels
}

\author{
Thomas A. Clay ${ }^{1,2, *}$, Richard A. Phillips ${ }^{2}$, Andrea Manica $^{1}$, Hazel A. Jackson ${ }^{3}$, \\ M. de L. Brooke ${ }^{1}$ \\ ${ }^{1}$ Department of Zoology, University of Cambridge, Downing Street, Cambridge CB2 3EJ, UK \\ ${ }^{2}$ British Antarctic Survey, Natural Environment Research Council, High Cross, Madingley Road, Cambridge CB3 0ET, UK \\ ${ }^{3}$ Durrell Institute of Conservation and Ecology, School of Anthropology and Conservation, University of Kent, \\ Marlowe Building, Canterbury, Kent CT2 7NR, UK
}

\begin{abstract}
The South Pacific Gyre is the world's largest expanse of oligotrophic ocean and supports communities of endemic gadfly petrels Pterodroma spp., yet little is known about their foraging ecology in this nutrient-poor environment. We tracked Murphy's petrels Pterodroma ultima with geolocators from Henderson Island, Pitcairn Islands, for 2 consecutive years (2011 to 2013). During pre-laying exodus, petrels travelled south and southwest of the colony, with males travelling further than females to more productive waters. During incubation, birds foraged at the southern and eastern edges of the Gyre, with some travelling over $4800 \mathrm{~km}$ from the colony, the greatest recorded foraging range of any breeding seabird. During non-breeding, the petrels migrated to the Subarctic Gyre in the North Pacific to forage in cool, mesotrophic waters. Habitat models revealed that these birds do not have clear preferences for oceanographic (such as fronts or eddies) or topographic (seamounts) features, generally favouring deep and unproductive waters. Analyses of activity patterns indicated Murphy's petrels are amongst the most active of all seabirds, particularly during incubation when they spent ca. 95\% of their time at sea in flight. The birds did not appear to forage during darkness, but flight activity peaked at dawn, particularly during non-breeding, suggesting they feed on mesopelagic prey that are diel vertical migrants. At-sea protection for such a wide-ranging species would require management at huge spatial scales, and hence in the short term, the principal focus for conservation should be on eliminating the immediate threat from invasive mammals at breeding sites.
\end{abstract}

KEY WORDS: Subtropical gyre · Gadfly petrel · Pelagic ecosystem • Trans-equatorial migration • Sexual segregation $\cdot$ Seabird $\cdot$ Activity patterns $\cdot$ Biologging

\section{INTRODUCTION}

Many species traverse considerable portions of the Earth's surface to take advantage of ephemeral food supplies (Dingle 1996). In particular, pelagic seabirds have low movement costs and may undertake extensive trans-equatorial migrations in order to exploit seasonally productive areas (Shaffer et al. 2006, Guilford et al. 2009, Dias et al. 2011). In temperate and polar re-

*Corresponding author: thomas.a.clay@hotmail.co.uk gions, predictable prey patches form around physical oceanographic features such as shelf- and ice-edges and upwellings (Weimerskirch 2007), leading to large aggregations of seabirds and other marine predators (Block et al. 2011). In contrast, in tropical and subtropical oceans, the presence of a permanent thermocline prevents the enrichment of surface layers, and as a result, primary production is generally low year-round (Ashmole 1971, Longhurst \& Pauly 1987).

(C) The authors 2017. Open Access under Creative Commons by Attribution Licence. Use, distribution and reproduction are unrestricted. Authors and original publication must be credited.

Publisher: Inter-Research · www.int-res.com 
As their food resources are patchily distributed, tropical seabirds have evolved specific foraging adaptations that enable them to search large areas efficiently (Ballance \& Pitman 1999, Weimerskirch et al. 2005a). Many species have distinctive wing morphologies or feed in association with sub-surface predators such as tuna (Scombridae) or dolphins (Delphinidae) that drive prey to the surface (Au \& Pitman 1986, Spear \& Ainley 1998, Catry et al. 2009). For example, in the eastern tropical Pacific, selection for flight proficiency in terns (Sternidae) and petrels (Procellariidae) is associated with their use of less productive waters, reducing competition with larger species such as boobies Sula spp. that gather around schools of tuna in more productive regions (Ballance et al. 1997).

Whilst research on tropical seabirds has increased over the last 2 decades (e.g. Ballance et al. 1997, Congdon et al. 2005, Jaquemet et al. 2005, Le Corre et al. 2012), little is known about their foraging ecology in some of the ocean's least productive areas, the subtropical gyres, where the circulation of currents prevents upwelling of nutrients (Longhurst 2007). In the North Pacific, Hawaiian albatrosses and other marine predators target the North Pacific Transition Zone (NPTZ), a highly productive region north of the North Pacific Gyre, between subarctic and subtropical water masses (Polovina et al. 2001, Hyrenbach et al. 2002, Kappes et al. 2010). In contrast, the South Pacific Gyre is permanently oligotrophic (Dandonneau et al. 2004), and much less is known about how the region's marine predators satisfy their energetic demands (Mannocci et al. 2014). Despite the impoverished oceanic environment, many islands support large populations of pelagic seabirds such as gadfly petrels Pterodroma spp., a large group (34 species) of small to medium sized petrels whose breeding colonies range from north temperate to subantarctic waters.

A large proportion of gadfly petrels (76\%) are classified by the International Union for the Conservation of Nature (IUCN) as threatened (Vulnerable, Endangered or Critically Endangered) or Near-Threatened, principally due to predation by introduced mammals at their breeding sites (BirdLife International 2010). Knowledge of their at-sea distributions is often limited to shipboard observations, where data collection can be challenging as these highly pelagic birds are usually observed in very low densities (Spear et al. 2007); however, a few species have been tracked using geolocators in recent years (Rayner et al. 2008, Pinet et al. 2011, Ramirez et al. 2013, Ramos et al. 2016, Nicoll et al. 2017). In the Pacific Ocean, where the majority (21 of 34 species) breed (Brooke 2004), there is published information on the movements of just 5 species, all confined to New Zealand and Australian breeding sites (MacLeod et al. 2008, Rayner et al. 2008, 2012, 2016, Priddel et al. 2014).

Henderson Island $\left(24^{\circ} 20^{\prime} \mathrm{S}, 128^{\circ} 20^{\prime} \mathrm{W}\right)$ is an uninhabited island of the UK Overseas Territory of the Pitcairn Islands and is one of the most important breeding sites in the world for gadfly petrels (Brooke et al. 2010). The island is the principal breeding site of the Henderson petrel Pterodroma atrata (>95\% of world's population), a major breeding site for Kermadec $P$. neglecta and herald $P$. heraldica petrels, and holds populations of Murphy's P. ultima and (possibly) Phoenix $P$. alba petrels. All species are thought to have been at much higher numbers before the arrival of Polynesians and introduction of the Pacific rat Rattus exulans almost 1000 yr ago (Steadman \& Olson 1985, Brooke 1995). Due to the paucity of studies on the movements of gadfly petrels from the subtropical South Pacific, very little is known about how these species use the marine environment, or at-sea threats.

Using miniaturised geolocators, we studied the movements of Murphy's petrels across 2 yr. Unlike their sympatric congeners, Murphy's petrels breed during the austral winter, laying more or less synchronously, which facilitates device deployment and retrieval (Brooke 1995). They have amongst the longest incubation shifts of any seabird, averaging $19.3 d_{i}$ it has been suggested that breeding birds could travel as far as the California coast, where they have been observed in June and July (Bailey et al. 1989, Brooke 1995). These particularly long trips may reflect the lack of available prey in the oligotrophic environment around their breeding colonies, but their oceanographic habitat preferences are unknown. Initial dietary analysis suggests that birds might feed nocturnally on bioluminescent squid (cranchiids, histioteuthids and onychoteuthids; Imber et al. 1995); however, few direct observations have been made of foraging birds (Spear et al. 2007).

Gadfly petrels are sexually monomorphic, yet tracking studies have revealed that males and females forage in distinct areas during pre-laying exodus (Pinet et al. 2012, Rayner et al. 2012). For example, male Barau's petrels $P$. barauii in the tropical Indian Ocean use more productive regions than females - possibly in preparation for the first long incubation stint, which is always taken by the male (Brooke 1995, Pinet et al. 2012). Given that Murphy's petrels have even longer incubation shifts, we might expect sex differences in energetic requirements 
early in the breeding period to be reflected in their foraging behaviour. In this study, we investigated for the first time, the movements, activity patterns and habitat preferences of Murphy's petrels during the breeding and non-breeding periods. In particular, we aimed to (1) define accurate breeding and migration schedules, (2) identify their main foraging grounds, (3) characterize marine habitats, (4) examine activity budgets, including the degree of nocturnal activity and (5) investigate sex differences in movements, distributions and habitat preferences.

\section{MATERIALS AND METHODS}

\section{Study species and site}

Murphy's petrel is a sexually monomorphic, surface-nesting species that breeds in the Pitcairn Islands and French Polynesia in the central South Pacific Ocean. Fieldwork took place in July 2011 and July 2013 on Henderson Island where $2500 \pm$ 500 pairs breed (Brooke 1995). Murphy's petrels suffer from chick predation by Pacific rats, usually within the first $5 \mathrm{~d}$ after hatching, and have very low breeding success (<10\%) (Brooke 1995, Brooke et al. 2010, Torr \& Brown 2012).

\section{Geolocator tracking}

We deployed 25 geolocator-immersion loggers (Mk18H; British Antarctic Survey) on incubating or brooding adults in July 2011. In July 2013, we retrieved and successfully downloaded 18 devices (72\%), including both devices from 5 pairs of birds. Loggers measured $17 \times 10 \times 6.5 \mathrm{~mm}$ and weighed $1.9 \mathrm{~g}$, and were attached to a plastic ring on the tarsus. The mass of the logger, rings and cable tie was well below the limit recommended for flying seabirds (Phillips et al. 2003), based on a mass of 400 to $500 \mathrm{~g}$ for this species (Brooke 1995). All birds except one were sexed using DNA from contour feathers. The exception was assigned as male since its partner was female.

Loggers sampled light every $1 \mathrm{~min}$, recording the maximum value every $5 \mathrm{~min}$ (Afanasyev 2004). Light data were processed using the BASTrak software suite (British Antarctic Survey) based on the timings of sunrise and sunset determined from thresholds in the light curves. Latitude was derived from the daylight length and longitude from the timing of local midday relative to Greenwich Mean Time and day of the year, providing 2 locations $\mathrm{d}^{-1}$ with a mean accu- racy of $186 \pm 114 \mathrm{~km}$ in pelagic seabirds (Phillips et al. 2004a). We removed locations derived from light curves with obvious interruptions around dawn or dusk, and periods around the equinox (2 to $4 \mathrm{wk}$ ), when latitude cannot be estimated reliably. The loggers also tested for saltwater immersion every $3 \mathrm{~s}$, storing the sum of positive tests (between 0 and 200) at the end of each 10 min period, with each period categorised as daylight or darkness based on the minimum light level recorded by the logger, which corresponded approximately to civil twilight (when the sun is $6^{\circ}$ below the horizon).

As nests could not be monitored during the study period, we assigned breeding stage and phenology based on a combination of movements and activity patterns (see the Supplement at www.int-res.com/ articles/suppl/m579p139_supp.pdf for details). Routes taken to and from non-breeding areas could not be determined because birds migrated during equinox periods. We assumed that over the study period, hatchling survival was low, and as it was challenging to identify early chick-rearing trips using immersion data, even within pairs (Fig. 1), we made no attempt to assign breeding success to tracked birds. Consequently, movements from end of incubation to northbound migration were classed as 'late breeding'. This period was removed from analysis of activity patterns, as it was not clear whether dry periods represented time spent at the colony or flying, whereas this distinction is obvious during incubation.

\section{Spatial analysis}

We calculated maximum ranges using great circle distances in the R package 'fields' (Nychka et al. 2016). As birds appeared to use 2 main foraging strategies during incubation, we classified long looping trips eastwards as 'east' and shorter trips southward as 'south'. We investigated the influence of sex and year differences on movement characteristics and timings of key events (see Table S1 in the Supplement), within a generalized linear mixed-effects model (GLMM) framework in the 'lme4' package in R (Bates et al. 2015). We used a Gaussian error structure for all models except for incubation trip type (east or south), where a binomial structure was used. We included sex, year and their 2-way interaction as explanatory covariates, as well as the random effect of individual identity. For models comparing incubation duration and maximum distance travelled, we included trip type as a fixed effect along with sex and year. For all model comparisons, we used Akaike's information 


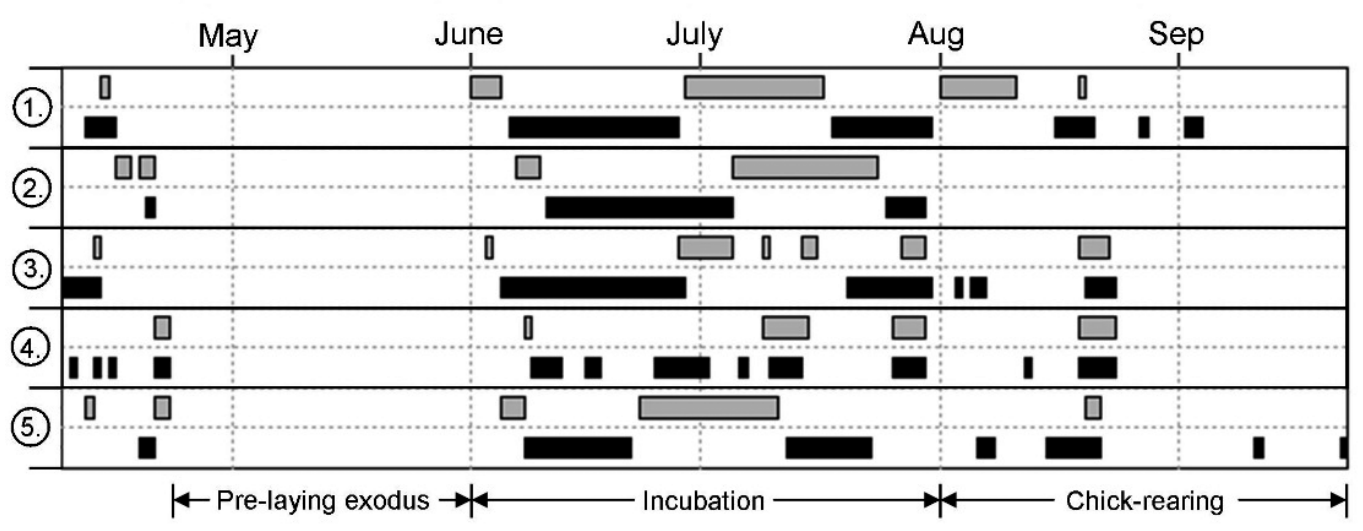

Fig. 1. Attendance patterns in 5 pairs of Murphy's petrels during the 2012 season, determined from immersion data. Grey shading: females; black shading: males. Each pair is numbered. Birds returned to the colony in mid- to late April, before engaging in a pre-laying exodus. Females returned slightly earlier to lay the egg, which preceded a male-female-male pattern of progressively shorter incubation shifts. Brooding occurred immediately after hatching (late July to mid-August). The fates of the chicks were unknown

criterion (AIC) values to rank all possible model combinations according to their degree of parsimony. Where multiple models were within 2 AIC units of the best supported model, the most parsimonious model was chosen (Burnham \& Anderson 2004, Arnold 2010).

We created utilisation distribution (UD) kernels to compare patterns of space use across the annual cycle. Plots of the increase in kernel area with isopleth level for each individual and stage indicated that the $50 \%$ kernel was the most appropriate for cross-stage comparisons of core areas. The $95 \%$ kernel was considered to represent the general use area. To control for differences between individuals, separate UDs were generated for each bird, and then merged to ensure equal representation for the population. We selected a grid size of $50 \mathrm{~km}$ and smoothing parameter of $200 \mathrm{~km}$ to account for geolocator error (Phillips et al. 2004a, 2005). We investigated whether space use differed between sexes and years for each breeding stage. We calculated observed overlap in core and general use areas using Bhattacharyya's affinity (BA), which is the most appropriate measure of quantifying similarity among UD estimates (Fieberg \& Kochanny 2005). BA estimates range between 0 and 1 , representing no similarity between UDs (or overlap) and identical UDs (or complete overlap), respectively. We used a randomization procedure to test the null hypothesis that there was no difference in spatial distributions. To test for differences in sex and year, we randomly reassigned bird identities without replacement and calculated overlap scores for 1000 iterations, maintaining the same ratios observed; $p$-values were determined as the proportion of randomized overlaps that were smaller than the observed (Breed et al. 2006). Kernel analyses were carried out using the 'kernelUD' and 'kerneloverlap' functions in the R package 'adehabitatHR' (Calenge 2006).

\section{Habitat analysis}

We calculated habitat preferences of the tracked petrels by comparing the environmental characteristics of the locations where animals were recorded to be present relative to areas that were available (useavailability) using binomial generalized additive models (GAMs) with a logit link function (Aarts et al. 2008). For each tracking location, we randomly sampled 50 matched pseudo-absences within an area defined by the minimum convex polygon of all observed locations, which was then expanded by $200 \mathrm{~km}$ to account for geolocator error (Clay et al. 2016). The appropriate number of pseudo-absences was determined according to Zydelis et al. (2011) (see the Supplement for details).

Environmental predictor variables were selected as proxies of oceanographic and topographic features known to be of importance to pelagic seabirds (e.g. Hyrenbach et al. 2006, Kappes et al. 2010): (1) ocean floor depth was sampled from the GEBCO bathymetric dataset (IOC 2003); (2) sea surface temperature (SST; indicative of water mass) and (3) chlorophyll a concentration ( $\mathrm{chl} a$; an indicator of primary productivity) were obtained by the MODIS sensor and were downloaded from the OceanColour website (http:// oceancolor.gsfc.nasa.gov/) at 4 and $7 \mathrm{~km}$ resolutions, respectively; (4) eddy kinetic energy (EKE), and (5) sea level anomaly (SLA), indicators of mesoscale turbulence, were delayed-time products and were 
extracted from AVISO (www.aviso.oceanobs.com) at a $0.25^{\circ}$ resolution; (6) wind speed (wind; linked to movement costs and prey availability), was obtained from the ASCAT satellite and downloaded from Ifremer (http://cersat.ifremer.fr/) at a $0.25^{\circ}$ resolution. All dynamic variables (except wind) were extracted using Marine Geospatial Ecology Tools (MGET) for ArcGIS v.10.1 (Roberts et al. 2010). Daily composites were averaged over a $7 \mathrm{~d}$ rolling window, except $\mathrm{chl}$ $a$, for which a $15 \mathrm{~d}$ window was used. All variables were resampled to a $0.25^{\circ}$ resolution, corresponding to the coarsest scale of all datasets, and were centred on the date of each location. To account for geolocator error, a buffer was created around each observed location and pseudo-absence, and the median value for the environmental variable was calculated. Two further variables were also calculated from the standard deviation of the mean of values within each buffer: (7) depth slope (indicative of topographic features), and (8) SST gradient (a proxy for thermal fronts). Additionally, (9) the distance to the colony was extracted for locations during the breeding season, to represent the central-place foraging constraint, and (10) tracking year was also included. Murphy's petrels have previously been sighted in the vicinity of a seamount in the North Pacific (Haney et al. 1995), and as a result we initially considered distance to the nearest seamount (a topographically distinct feature with an elevation $>1000 \mathrm{~m}$ above the seafloor; Yesson et al. 2011) as a predictor in our models. However, initial analyses revealed that birds either showed no preferences or avoided areas around seamounts; as the latter is counterintuitive, we excluded the variable from further analyses.

All records with incomplete information (e.g. due to cloud cover) were removed before analyses, which represented around $10 \%$ of all locations. We tested for collinearity between variables (Spearman's rank correlation $>0.5$ ), and where 2 variables were correlated they were not included in the same model. We standardized variables to improve the spread of the data: EKE, chl $a$ and depth slope were log transformed and SST gradient was square-root transformed. GAMs allow the possibility of non-linear responses to predictor variables and were fitted separately for each breeding stage within the ' $m g c^{\prime}$ ' package in $\mathrm{R}$ (Wood 2006). Smoothers were produced using cubic regression splines with shrinkage to reduce overparameterization, as variables are penalized during fitting (Wood 2006). We initially set the maximum number of knots to 4 to reduce over-fitting, increasing the number if model response curves did not match the raw data.
Cross-validation was used to select the most appropriate predictor variables and for assessing model performance (Aarts et al. 2008, also see Carneiro et al. 2016 for further details). Each individual was assigned as a data fold. Iteratively, each model was trained on all-but-one fold and tested on the remaining one, withholding each fold in turn. We used area under the receiver operator characteristic curve (AUC) to evaluate model performance in the 'PresenceAbsence' package in R (Freeman 2012). Values of 0.5 to $0.7,0.7$ to 0.9 and $>0.9$ represent poor, reasonable and very good model performance, respectively. A forwards selection procedure was used to initially fit all single predictor models and then add each variable in turn, until there was no further increase in AUC score. The significance of the stepwise inclusion of variables was assessed with paired $t$-tests. Cross-validation is a conservative approach to variable selection but prevents the inclusion of redundant variables (Aarts et al. 2008). In order to test for sex differences in the responses of birds to habitat variables, we ran paired $t$-tests to determine if the inclusion of the sex-specific smoother produced significantly different AUC scores (Clay et al. 2016).

\section{Activity analysis}

We selected activity metrics that are likely to reflect at-sea foraging and flight behaviour of petrels in daylight and darkness (Spear et al. 2007): proportion of time spent on the water, duration of flight bouts (in $\mathrm{min}$ ) and number of landings (wet bouts) $\mathrm{h}^{-1}$. Flight and wet bouts were defined as continuous 10 min periods spent entirely dry or during which the bird spent at least $3 \mathrm{~s}$ on the water, respectively. Immersion data were recorded from 2 individuals for fewer than 6 mo and were excluded from activity analyses. In order to determine if changes in photoperiod (day length) with latitude and season influence the interpretation of our results, we also compared the number of landings and hours spent on the water per day ( $24 \mathrm{~h}$ period).

Activity data were split by breeding stage, excluding dry periods spent at the colony, and daily patterns were compared between stages, year and daylight versus darkness (a categorical variable) using GLMMs with each activity metric as the response variable and individual identity as a random effect. To increase normality of distributions, we square-root transformed the number of landings $\left(\mathrm{h}^{-1}\right.$ and $\left.\mathrm{d}^{-1}\right)$ and the number of hours spent on water, log transformed the flight bout durations, and arcsine transformed the propor- 
tion of time spent on water. We tested the importance of all combinations of predictors and their interactions using AIC values (as above), and compared stages using Tukey post hoc tests in the 'multcomp' package in R (Hothorn et al. 2008).

In order to investigate diel variation in activity budgets, activity data were then split into 4 categories: darkness, morning twilight (dawn to sunrise), daylight and evening twilight (sunset to dusk) based on the corresponding light data. Light values of 64 and 0 represent daylight and darkness periods, respectively, and values $>0$ and $<64$ correspond roughly to periods of civil twilight. We removed activity data associated with light data with obvious interference around sunrise and sunset. The proportion of time spent on the water during daylight, darkness and twilight periods was compared using GLMMs, followed by post hoc Tukey tests. Models were run separately for nonbreeding, incubation and pre-laying exodus. Observed means $( \pm \mathrm{SD})$ are given in tables to enable comparisons with other studies (as in Mackley et al. 2010). All analyses were conducted in the software $R$ v.3.1.1 (R Core Team 2014), unless otherwise stated.

\section{RESULTS}

\section{Distribution and annual cycle}

Murphy's petrels showed clear separation between breeding and non-breeding grounds, when they used the South and North Pacific, respectively (Fig. 2). During the pre-laying exodus, birds foraged south and southwest of the colony around the Subtropical Convergence, east of the Chatham Rise ( $50 \%$ UD, 25 to $50^{\circ} \mathrm{S}, 160$ to $115^{\circ} \mathrm{W}$; Fig. 2c). There was clear sexual segregation during this period in both core areas (50\% UD, observed overlap 0.08 and randomized overlap $0.23 \pm 0.06, \mathrm{p}<0.019$; Fig. 3b, Table 1), and general use areas (95\% UD, observed overlap 0.72 and randomized overlap $0.82 \pm 0.04, \mathrm{p}<$ 0.023; Fig. 3b, Table 1), but no differences between sexes in mean longitudes or latitudes (see Table S1 in the Supplement). Males ranged further from the colony $(3826 \pm 449 \mathrm{~km})$ than females $(2921 \pm 634 \mathrm{~km})$, but did not differ in timing of movements (Table S1). Birds departed from, and returned to the colony significantly later in 2013 (26 April $\pm 7 \mathrm{~d}$ and 10 June \pm $6 \mathrm{~d}$ ) than in 2012 (18 April $\pm 7 \mathrm{~d}$ and 4 June $\pm 6 \mathrm{~d}$ ), and consequently the duration of the pre-laying exodus was marginally shorter (47 $\pm 3 \mathrm{~d}$ in 2012 and $45 \pm 3 \mathrm{~d}$ in 2013; Table S1). We found no evidence of sexual segregation during any other stages of the annual cycle in either core or general use areas (Table 1, Fig. 3), nor did we find evidence of differences in these distributions between years (Table 1).

During incubation, birds foraged over large areas of subtropical waters south and east of the colony (50\% UD, 10 to $45^{\circ} \mathrm{S}, 140$ to $80^{\circ} \mathrm{W}$; Fig. 2d). Females departed for, and returned from, their first incubation trip earlier (11 June $\pm 6 \mathrm{~d}$ and 1 July $\pm 7 \mathrm{~d}$ ) than males (27 June $\pm 7 \mathrm{~d}$ and 14 July $\pm 7 \mathrm{~d}$ ); however, their trip durations were not significantly different $(20 \pm 5$ and $18 \pm 4$ d, respectively; Table S1). Trips were significantly longer in 2012 than 2013 (20 \pm 3 and $17 \pm 5 \mathrm{~d}$, respectively; Table S1). For 3 birds, we identified a second incubation trip in 2012 (departing on 19 July $\pm 8 \mathrm{~d}$ and returning on 2 August $\pm 8 \mathrm{~d}$ ); these second trips appeared to be shorter $(14 \pm 3 d, n=3)$ than the first trips, but the small sample precluded a statistical comparison. We classified incubation trips into either short trips south $(29 \% ; 2012 \mathrm{n}=5,2013 \mathrm{n}=4)$ or long looping trips east $(68 \% ; 2012 \mathrm{n}=13,2013 \mathrm{n}=8)$ of the colony, except one (2012) which was a long looping trip (19 d) west of the colony.

Trip duration was not influenced significantly by trip type (Table S1); however, birds that took trips east ranged further from the colony (mean maximum distance of south trips: $2012 \pm 600 \mathrm{~km}$; east trips: $3757 \pm 829 \mathrm{~km}$; Table S1). Trips east predominantly followed an anti-clockwise looping pattern (although one eastward trip of $21 \mathrm{~d}$ was clockwise), appearing to take advantage of trade winds in the southeast Pacific, particularly for the return journey (Fig. 4). Birds tended to travel southeast to the Subtropical Front and then northeast past Easter Island to an area off the Humboldt Upwelling west of Peru, around $3500 \mathrm{~km}$ east of Henderson Island. Maximum distances from the colony were $4161 \mathrm{~km}$ in 2012 and $4898 \mathrm{~km}$ in 2013. Trips south were generally $1000 \mathrm{~km}$ southeast or southwest of the colony and appeared to target the Subtropical Front (Figs. 2d \& 4).

Although we could not determine from activity or movements whether birds that were tracked after hatching retained a chick, the last dry night at the colony did not differ between years (25 August \pm $18 \mathrm{~d}$; Table S1), suggesting a similar pattern of colony attendance in 2011 and 2012. During this period, birds foraged closer to the colony than during incubation, sometimes using an area in the southeast Pacific towards northern Chile $\left(50 \%\right.$ UD, 15 to $50^{\circ} \mathrm{S}$, 140 to $95^{\circ} \mathrm{W}$; Fig. 2e).

There were no significant effects of year on any of the migration metrics (Table S1). Birds migrated northwest across the Pacific, departing the eastern South Pacific on 22 October $\pm 18 \mathrm{~d}$ and arriving at the 

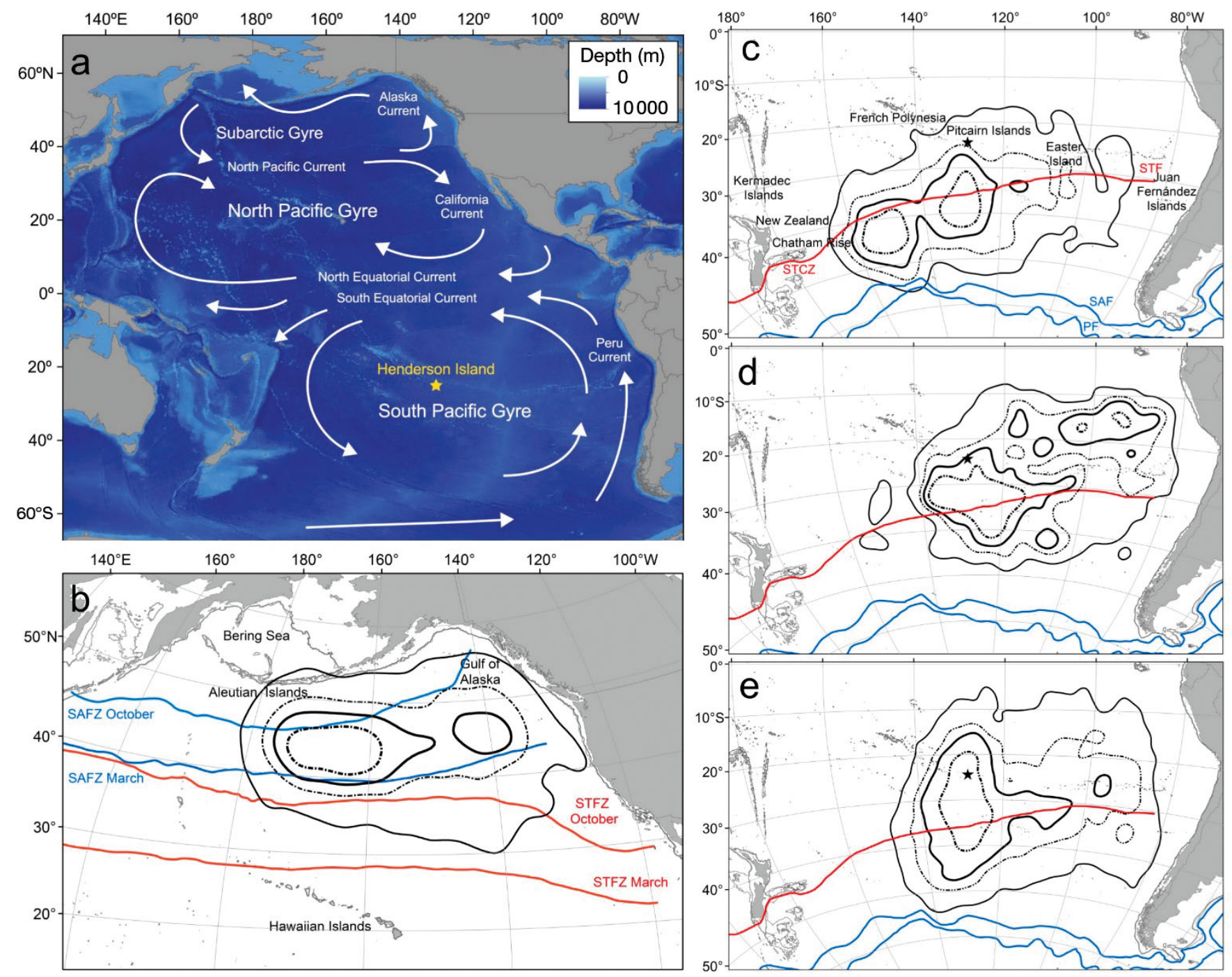

Fig. 2. (a) The Pacific Ocean, showing bathymetry in blue shading and the positions of main ocean gyres and directions of currents in white text and arrows, respectively. $25 \%(-\boldsymbol{C}), 50 \%(\boldsymbol{C}), 75 \%(--)$ ) and $95 \%(\longrightarrow)$ utilisation distributions (UDs) of Murphy's petrels tracked with geolocator-immersion loggers from Henderson Island ( $\star$ ) are shown during (b) nonbreeding, (c) pre-laying exodus, (d) incubation and (e) late breeding. In the North Pacific, the positions of the Subtropical Frontal Zone (STFZ; red) and Subarctic Frontal Zone (SAFZ; blue) were generated from isotherms for the first (October) and last (March) months of non-breeding (based on Hyrenbach et al. 2002), whereas in the South Pacific the positions of fronts are year-round averages. SAF Subantarctic Front; PF: Polar Front; STCZ: Subtropical Convergence Zone; STF: Subtropical Front

western edge of their non-breeding grounds in the central North Pacific, over $8000 \mathrm{~km}$ from Henderson Island on 3 November $\pm 27 \mathrm{~d}$. Whilst in the North Pacific, Murphy's petrels used 2 core areas at approximately 40 to $45^{\circ} \mathrm{N}$, one south of the Aleutian Islands around the Subarctic Front (175 to $\left.155^{\circ} \mathrm{W}\right)$, and the other further east, south of the Gulf of Alaska (145 to $135^{\circ} \mathrm{W}$ ) (Fig. 2b). The residency period in the North Pacific lasted $154 \pm 27$ d, after which birds departed on 6 April $\pm 15 \mathrm{~d}$, travelling almost directly south, returning to the South Pacific on 17 April $\pm 18 \mathrm{~d}$ and spending the first night at the colony on 18 April \pm $16 \mathrm{~d}$. There was no difference in the duration of outbound and return trans-equatorial migrations (GLMM best fitting model: $10 \pm 3$ and $11 \pm 4 \mathrm{~d}$, respectively).

\section{Habitat use}

Murphy's petrels used deep (>3000 m) pelagic waters across the annual cycle, which were of oligotrophic (chl $a<0.07 \mathrm{mg} \mathrm{m}^{-3}$; sensu Polovina et al. 

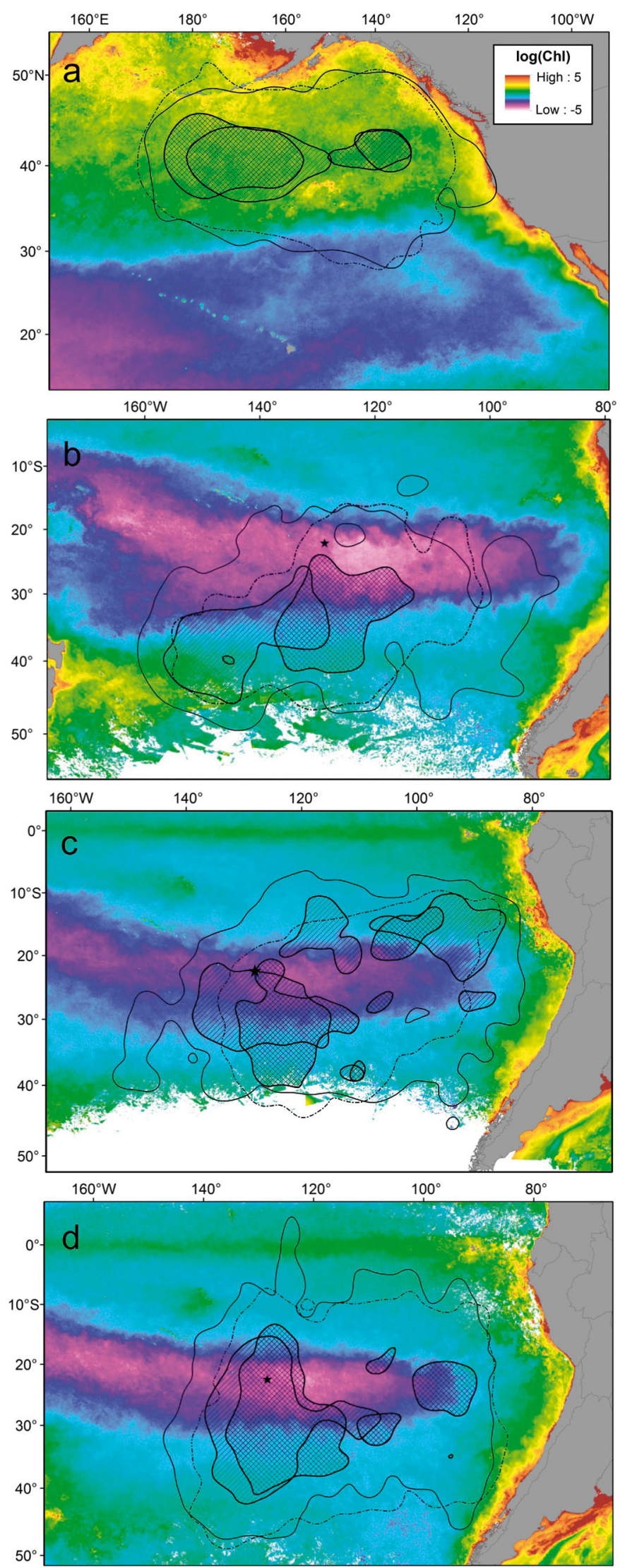

2008) and mesotrophic productivity during breeding and pre-laying exodus, respectively, and of much higher productivity during non-breeding (Fig. 3). The best models explaining Murphy's petrel habitat performed reasonably well for non-breeding (mean of individual AUC scores: $0.85 \pm 0.03)$, incubation $(0.87 \pm 0.07)$ and late breeding $(0.76 \pm 0.06)$ periods, but performed poorly for pre-laying exodus $(0.67 \pm$ 0.06). The most important habitat predictors were, in order of decreasing importance, SST, depth slope and SLA for non-breeding, chl a for pre-laying exodus, SLA and EKE for incubation, and distance to the colony, SST and depth slope for late breeding (Table S2 in the Supplement). During non-breeding, SST was correlated with both EKE and chl $a$ and resulted in models with higher performance, so only SST was considered. Depth, SST gradient and wind were not considered to be important across the annual cycle, nor (surprisingly) was chl a during incubation and late breeding (Table S2). The effect of year was important during incubation but explained a negligible amount of deviance, and distance to the colony was not important during incubation or prelaying exodus.

Birds exhibited similar responses to some important habitat variables across breeding stages (SLA and depth slope). During non-breeding, tracked birds preferred cooler subarctic waters (particularly those around 8 to $10^{\circ} \mathrm{C}$ which are likely associated with the Subarctic Frontal Zone; Hyrenbach et al. 2002), with moderate depth gradients and positive SLA (Fig. 5). During pre-laying exodus, birds selected waters which were the most oligo- and mesotrophic from within their range, whereas during incubation birds foraged in areas with moderate, positive SLAs but low EKE (Fig. 5). During late breeding, birds generally foraged within around $2000 \mathrm{~km}$ of the colony in warmer, subtropical waters (around 12 to $20^{\circ} \mathrm{C}$ ) with moderate depth gradients (Fig. 5).

The inclusion of a sex-specific smoother significantly increased model performance during prelaying exodus only (Fig. 3, Table S3 in the Supplment). Males selected more productive habitats than

Fig. 3. Core (50\%) and general use (95\%) utilisation distributions (UDs) of male (hatched fill and solid lines, respectively) and female (cross-hatched fill and dashed lines, respectively) Murphy's petrels from Henderson Island ( $\star$ ) tracked during (a) non-breeding (October to March), (b) pre-laying exodus (April and May), (c) incubation (June and July) and (d) late breeding (August and September). The log of chl a concentration $\left(\mathrm{mg} \mathrm{m}^{-3}\right)$ is shown averaged across the period of interest 
Table 1. Observed and randomized overlap (Bhattacharyya's affinity, BA) of core (50\%) and general use (95\%) utilization distributions (UDs) of Murphy's petrels tracked with geolocator-immersion loggers in 2011-2012 and 2012-2013, compared between years and sexes in each breeding stage. Sexes are pooled for year comparisons and vice versa. Randomized overlaps are shown as a median \pm interquartile range. $p$ represents the proportion of randomized overlaps that were smaller than the observed. Significant differences $(\mathrm{p}<0.05)$ are shown in bold

\begin{tabular}{|c|c|c|c|c|c|c|}
\hline \multirow{2}{*}{ Class } & \multicolumn{3}{|c|}{$-50 \%$} & \multirow[b]{2}{*}{ Observed } & \multirow{2}{*}{$\begin{array}{l}-95 \% \\
\text { Randomized }\end{array}$} & \multirow[b]{2}{*}{$\mathrm{p}$} \\
\hline & Observed & Randomized & $\mathrm{p}$ & & & \\
\hline \multicolumn{7}{|l|}{ Sex } \\
\hline Non-breeding & 0.28 & $0.30 \pm 0.05$ & 0.36 & 0.90 & $0.89 \pm 0.03$ & 0.75 \\
\hline Pre-laying exodus & 0.08 & $0.23 \pm 0.06$ & 0.019 & 0.72 & $0.82 \pm 0.04$ & 0.023 \\
\hline Incubation & 0.15 & $0.17 \pm 0.04$ & 0.23 & 0.72 & $0.77 \pm 0.05$ & 0.14 \\
\hline Late breeding & 0.29 & $0.33 \pm 0.02$ & 0.058 & 0.88 & $0.88 \pm 0.02$ & 0.33 \\
\hline \multicolumn{7}{|l|}{ Year } \\
\hline Non-breeding & 0.27 & $0.30 \pm 0.05$ & 0.28 & 0.89 & $0.89 \pm 0.03$ & 0.63 \\
\hline Pre-laying exodus & 0.25 & $0.23 \pm 0.06$ & 0.69 & 0.83 & $0.82 \pm 0.04$ & 0.57 \\
\hline Incubation & 0.24 & $0.17 \pm 0.04$ & 0.99 & 0.83 & $0.77 \pm 0.05$ & 0.99 \\
\hline Late breeding & 0.31 & $0.33 \pm 0.02$ & 0.19 & 0.88 & $0.89 \pm 0.02$ & 0.44 \\
\hline
\end{tabular}

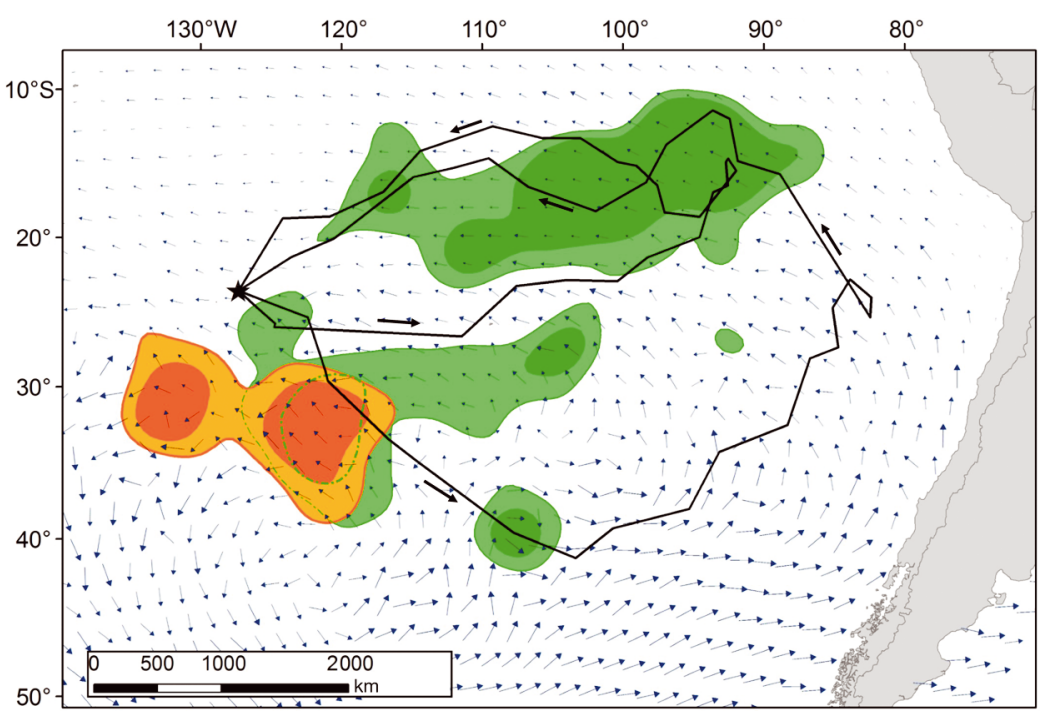

Fig. 4. Movement strategies of Murphy's petrels tracked with geolocationimmersion loggers from Henderson Island $(\star)$ during incubation, in relation to wind regimes. The $25 \%$ and $50 \%$ utilisation distributions (UDs) are shown for birds that undertook trips south (dark and light orange, respectively) of the colony and looping trips east (dark and light green, respectively) east of the colony towards the Humboldt Current. Examples of 2 looping trips are shown as black lines with black arrows indicating their direction. The averaged monthly wind speed and direction over the incubation period (June and July) are shown with blue arrows, with higher speeds represented by longer arrows

females, who foraged predominantly in oligotrophic waters (Figs. 3 \& 5). There were large ranges in individual AUC scores during the breeding stages (prelaying exodus: 0.53 to 0.80 ; incubation: 0.75 to 0.95 ; late breeding: 0.62 to 0.86 ) but not during non-breeding $(0.81$ to 0.90$)$, suggesting individual variation in foraging habitats during breeding.

\section{Activity patterns}

Activity patterns varied considerably during the annual cycle (Fig. 6, Table S4 in the Supplement). The best-fitting models explaining variation in all 5 activity metrics included the influence of daylight or darkness, breeding stage and their interaction, and the best-fitting model explaining the duration of flight bouts also included the fixed effect of year (Table S4). The greatest proportion of time spent sitting on the water was during the non-breeding period, followed by the outward and return migrations, pre-laying and incubation periods (all stages significantly different from each other except outward and return migrations; Tables $2 \&$ S5, the latter in the Supplement). In contrast, the landing rate was greatest during incubation, pre-laying exodus and outward migration, and least during non-breeding (Tables 2 \& S5). During pre-laying exodus and non-breeding, birds spent a greater proportion of time on the water at night, whereas during the other stages, birds spent a greater proportion of time wet during daylight (Table 2). Significant differences between stages were largely maintained when raw values were used instead of proportions, suggesting that changes in day length do not influence our results (Tables 2, S4 \& S5). Flight bout durations were shorter during non-breeding than during the other stages (Tables $2 \&$ S5). 
a
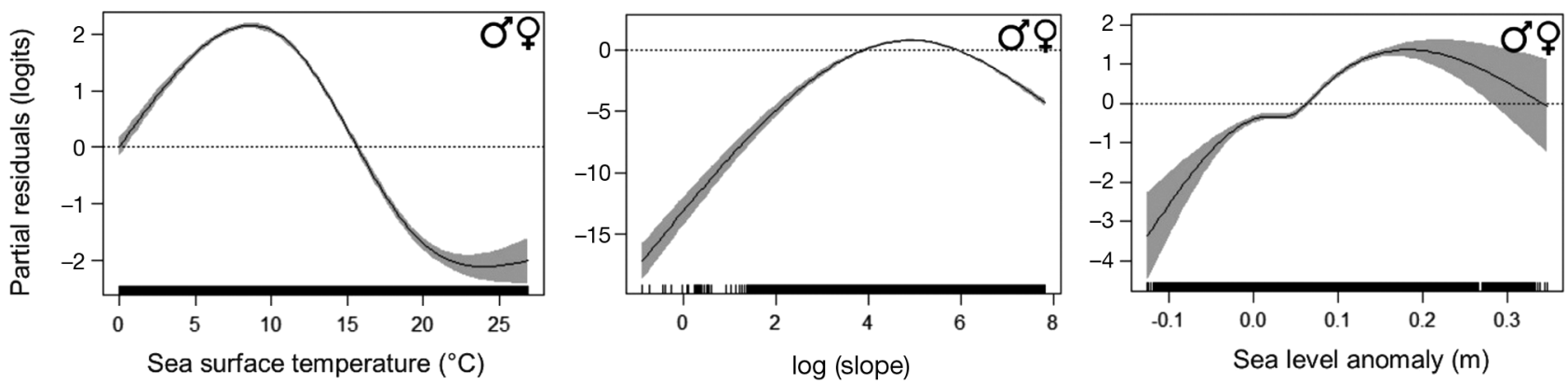

b

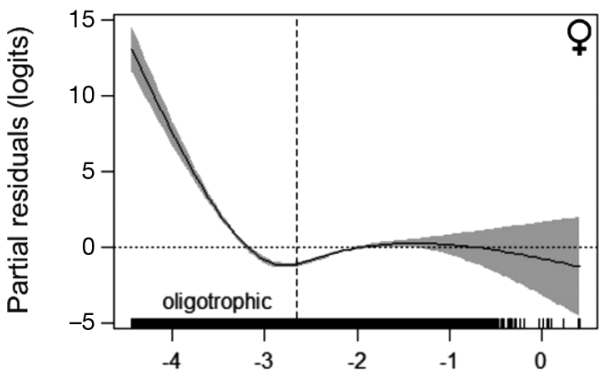

$\log$ (chlorophyll a concentration)

C

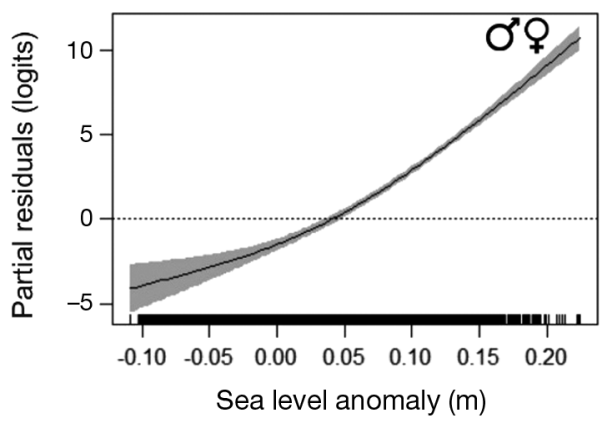

d

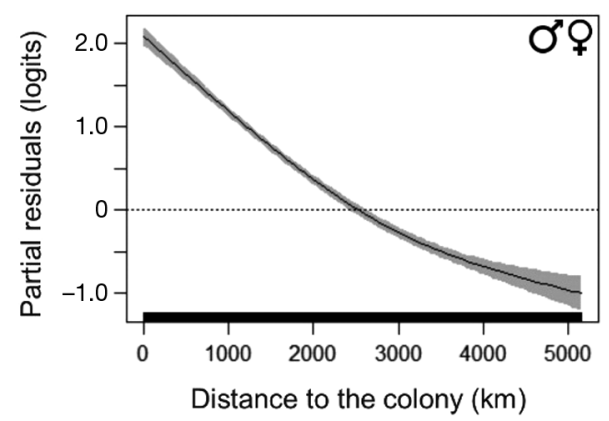

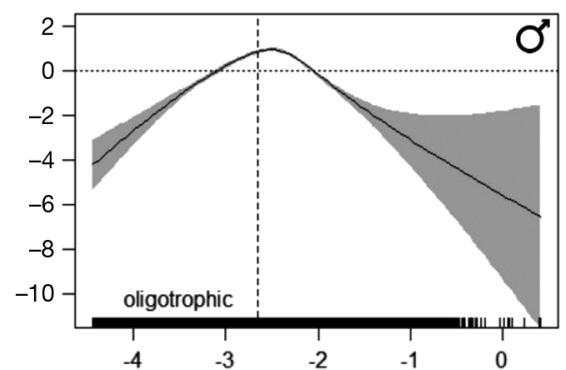

$\log$ (chlorophyll a concentration)

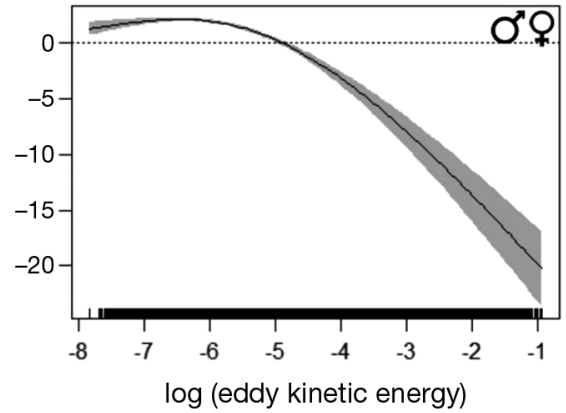

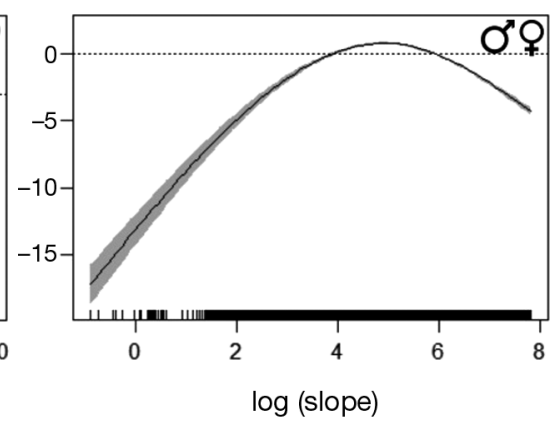

Fig. 5. Response curves of predictors retained in the most parsimonious models of Murphy's petrel habitat preferences during the (a) non-breeding, (b) pre-laying exodus, (c) incubation and (d) late breeding periods. Shaded grey areas: estimated $95 \%$ confidence intervals. Male and female symbols shown separately indicate sex-specific habitat responses. For plots of chl a concentration, vertical dashed lines indicate the cut-off for oligotrophic waters $\left(<0.07 \mathrm{mg} \mathrm{m}^{-3}\right.$; based on Polovina et al. 2008). Data 


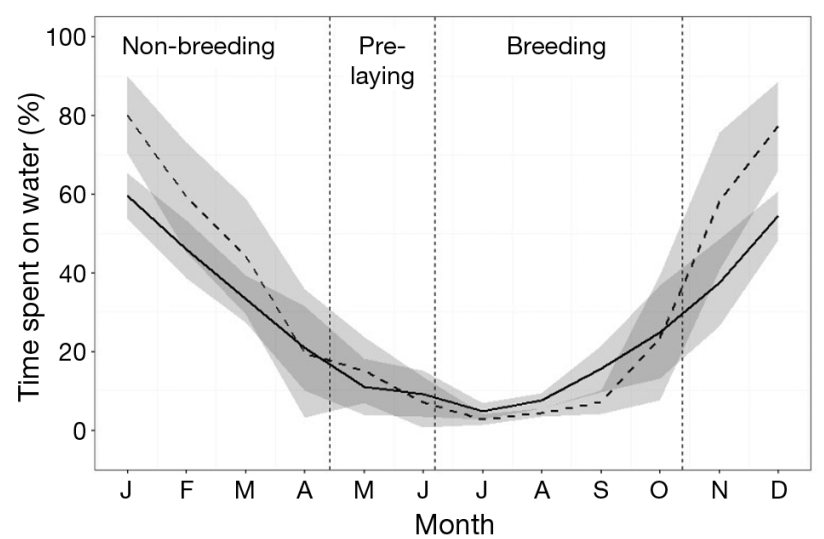

Fig. 6. Annual variation in the percentage of time Murphy's petrels tracked with geolocator-immersion loggers spend on water in daylight (solid line) and darkness (dashed line). Means $( \pm \mathrm{SD})$ of individual monthly averages are shown

Another set of models were used to investigate diel changes in activity budgets, separately for each breeding stage (Table S6 in the Supplement). During non-breeding, birds spent significantly more time flying during morning twilight than during daylight, darkness or evening twilight. In the period before sunrise, birds reduced the proportion of time spent on the water from over 40 to $7 \%$, and, over the course of the subsequent day, gradually reduced their flight activity such that there was no difference in activity budgets between evening twilight and darkness (Fig. 7, Table S7 in the Supplement). Differences between groups were similar but less pronounced during pre-laying exodus (proportion of time spent on water reduced from 14 to $7 \%$ ); birds flew more during morning twilight than during daylight and darkness (Fig. 7, Table S7). In contrast, during incubation, birds spent greater proportions of daylight hours on the water than during morning and evening twilights, and darkness ( $7 \%$ compared with 2 to $4 \%$; Fig. 7, Table S7).

\section{DISCUSSION}

\section{Year-round distribution and habitat preferences}

This study is the first to detail the movements of a seabird that breeds in the South Pacific Gyre, an extremely remote and understudied marine environment (Claustre \& Maritorena 2003). Murphy's petrels, tracked over 2 consecutive years, used distinct areas throughout the annual cycle, remaining in the South Pacific when breeding and conducting transequatorial migrations to the North Pacific during

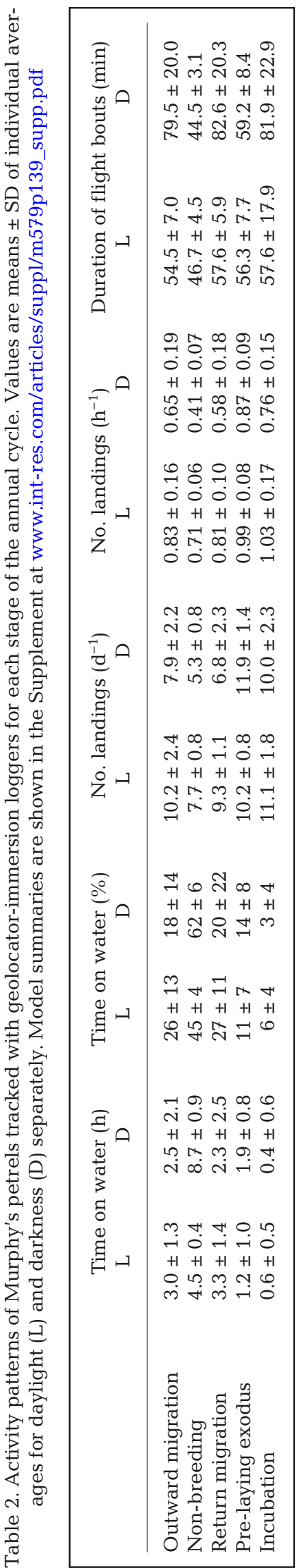




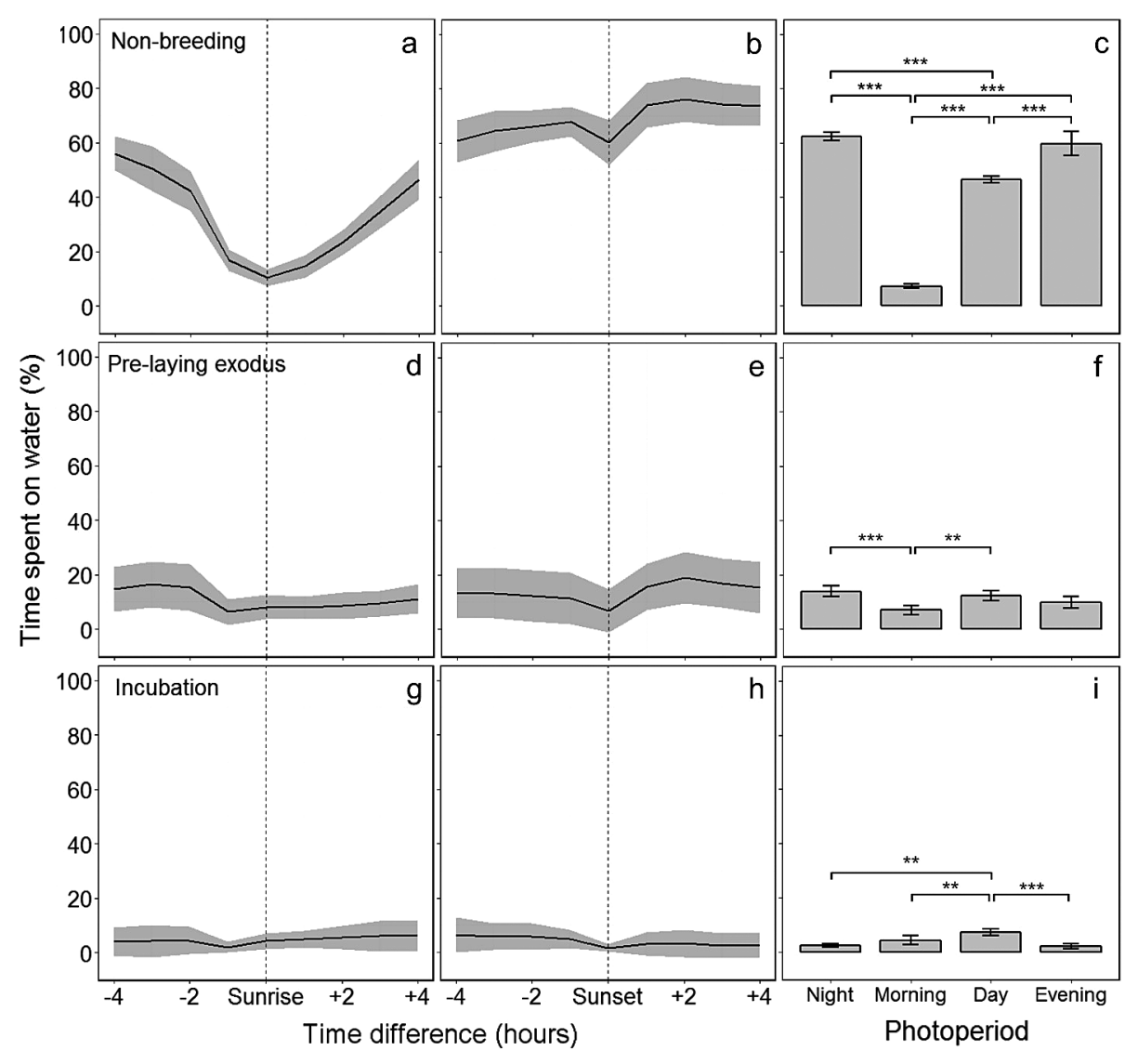

Fig. 7. Diel variation in the proportion of time spent on water by Murphy's petrels during $(\mathrm{a}-\mathrm{c})$ non-breeding, (d-f) pre-laying exodus and $(g-i)$ incubation. Hourly means $( \pm \mathrm{SD})$ were calculated for each individual and day, and are shown as number of hours before and after sunrise (left panels) and sunset (middle panels) to control for variable photoperiod (e.g. longer twilight periods at higher latitudes). Darkness (night), morning twilight (morning), daylight (day) and evening twilight (evening) were also split into discrete groups based on corresponding light data and are shown as bar plots (right panels) with asterisks denoting significant differences between groups: ${ }^{* *} \mathrm{p}<0.01$; ${ }^{* * *} \mathrm{p}<0.001$ non-breeding. There are few sightings of Murphy's petrels from ship-based surveys; they include small numbers observed off the coast of California and in the eastern tropical Pacific (Bartle et al. 1993, Haney et al. 1995, Spear et al. 2007). Given the chronological sequence of observations off California (April to June), in the Gulf of Alaska (July) and in the Hawaiian archipelago (September to November), Bartle et al. (1993) suggested that this species performs anticlockwise movements through the North Pacific during breeding. However, direct observations of the northward track of birds off Hawaii and the freshlymoulted plumage of birds off California led Howell (2012) to suggest a clockwise transit through the North Pacific during non-breeding, similar to that described here.

Energetic demands increase during breeding, and many seabirds select the most productive habitats (e.g. Péron et al. 2010). Murphy's petrels breed in the middle of the South Pacific Gyre, where ocean currents are relatively weak and there is minimal upwelling of deep water, and as a result consistently low primary productivity (D'Hondt et al. 2009). Our results indicate that Murphy's petrels have adapted to breeding in the 'largest oceanic desert' (Claustre \& Maritorena 2003) by travelling vast distances to forage at the southern and eastern edges of the Gyre during pre-laying and incubation. As a consequence, it might be expected that birds would select more productive regions from within their range; however, somewhat surprisingly, primary productivity was an important predictor only during the pre-laying exodus, during which model performance was poor and habitat preferences were for low productivity regimes.

Interestingly, males and females used mutually exclusive foraging areas during pre-laying, with different habitat preferences; males selected more productive waters downstream of the Chatham Rise, whilst females appeared to target the Subtropical Frontal Zone. In many seabirds, sexual segregation during breeding is attributed to size-mediated competitive exclusion or niche divergence (Shaffer et al. 2001, Phillips et al. 2004b, 2011). However, Murphy's petrels are sexually monomorphic and do not appear to segregate at sea during incubation or chickrearing. Therefore, pre-laying segregation may be related to different energetic requirements or repro- 
ductive roles in the early breeding season (Hedd et al. 2014, Quillfeldt et al. 2014). Like Murphy's petrels, Barau's petrels (Pinet et al. 2012) and Chatham petrels Pterodroma axillaris (Rayner et al. 2012) show sexual segregation during pre-laying, and the males travel further to more productive areas, suggesting that this behaviour might be common among gadfly petrels. Our results provide further support for the hypothesis that males use more productive regions than females to prepare for their long incubation shift (Pinet et al. 2012), and dietary analyses would shed light on whether they target specific prey during this period.

One of the most striking results of this study was the great distance travelled by Murphy's petrels during incubation trips, which is, as far as we are aware, the largest range of any seabird during breeding (reviewed in Pollet et al. 2014). As Murphy's petrels are known to have some of the longest incubation shifts (Warham 1990, Brooke 1995), they were predicted to range far from the colony; indeed, the maximum distance recorded $(4898 \mathrm{~km})$ is similar to the maximum estimate of $4600 \mathrm{~km}$ made by Brooke (1995). The tracked birds appeared to use 2 discrete foraging areas: the Subtropical Front to the south, and an area east of the colony towards the Humboldt Current. Individuals conducted long looping trips southeast of the colony, and may benefit from following trade winds (Weimerskirch et al. 2005b). Birds avoided the most productive areas in the South Pacific, including the eastern tropical region, probably to reduce competition with other seabirds (Ballance et al. 1997, Rayner et al. 2016), and they overlapped little with other gadfly species that spend the austral winter in the southeast Pacific (Rayner et al. 2011, 2012).

Mesoscale features such as eddies are known to be of importance to seabirds, particularly in tropical and subtropical waters where a deep thermocline prevents mixing of nutrients (Hyrenbach et al. 2006, Jaquemet et al. 2014). Although in our study the tracked birds associated with positive SLAs, these were not indicative of mesoscale eddies as birds also preferred areas with low geostrophic currents. Similarly, birds used oceanic regions with moderate depth slopes, and might be expected to aggregate around seamounts (Haney et al. 1995), yet we found no supporting evidence (see 'Materials and methods'). Indeed, as Murphy's petrels do not appear to target obvious oceanographic or topographic structures, they might select calm waters for easier visual detection of buoyant prey, such as moribund squid, which float close to the surface (Ballance \& Pitman 1999).
Towards the eastern boundaries of subtropical gyres, in areas offshore or downstream from upwellings, convergence zones form where upwelled water sinks below warmer surface waters, leading to aggregations of mesopelagic prey (Polovina et al. 2001, Saba et al. 2008). The eastern region of the South Pacific Gyre is also used extensively by leatherback turtles Dermochelys coriacea targeting zooplankton such as jellyfish (Saba et al. 2008, Shillinger et al. 2011). Mesopelagic prey, thought to be a dominant component of food webs in deep, oceanic waters (Ashmole 1971), often perform diel vertical migrations (DVMs) to the sea surface at night (Hays 2003), making them available to air-breathing predators such as turtles and seabirds (Regular et al. 2010, Shillinger et al. 2011). Analysis of Murphy's petrel diets during chick-rearing has indicated they feed predominantly on bioluminescent squid, emphasizing their reliance on DVM prey (Imber et al. 1995).

All procellariform species that breed outside the tropics and routinely cross the Equator on migration have a relatively synchronous laying period (Brooke 2004). As Murphy's petrels lay synchronously, in contrast to the other Pterodroma spp. on Henderson Island, it was assumed that they must be longdistance migrants (Brooke 1995). By visiting the North Pacific during the boreal winter, Murphy's petrels avoid competition with millions of shearwaters in the summer (Shaffer et al. 2006, Hedd et al. 2012). This might also explain the winter breeding schedule of the Providence petrel Pterodroma solan$d r i$, which migrates from the southwest Pacific to the northwest Pacific off Japan (Brooke 2004). Murphy's petrels spend the non-breeding period in the central and eastern North Pacific around the Subarctic Frontal Zone, a region also used by other marine predators at fairly low densities; such as the winterbreeding Laysan albatrosses Phoebastria immutabilis, wintering northern fulmars Fulmarus glacialis and Dall's porpoises Phocoenoides dalli (Springer et al. 1999, Hyrenbach et al. 2002). Unlike the foraging habitats of Murphy's petrels in the South Pacific, during winter and spring, strong westerlies cause mixing of nutrient-rich waters and help maintain productivity in the absence of sunlight (Bograd et al. 2004). Additionally, birds appear to use the NPTZ, which spans the Subarctic and Subtropical Frontal Zones, and is an important foraging and migration habitat for many species due to aggregations of mesopelagic prey (Robinson et al. 2012). For example, DVM squid seasonally migrate from spawning areas in the subtropics to the Subarctic Frontal Zone to feed on myctophid fishes (Watanabe et al. 2004, Ichii et al. 2009). 


\section{Year-round foraging behaviour}

Murphy's petrels adjusted their activity patterns across the annual cycle relative to the degree of central place constraint (Mackley et al. 2010). Birds spent more time flying during breeding, peaking at $95 \%$ of time at sea during incubation. Indeed, Murphy's petrels are one of the most active seabirds, to our knowledge more so than any other small petrel (Rayner et al. 2012, Navarro et al. 2013, Ramirez et al. 2013, Dias et al. 2016), presumably reflecting the need to commute to distant foraging grounds. The high frequency of landings during incubation suggests that birds forage continuously on route. As foraging strategies of seabirds are a function of their marine environment (Weimerskirch 2007), the extreme activity of Murphy's petrels is also likely to be related to the unpredictability of prey in the South Pacific, with birds searching at large scales (Weimerskirch et al. 2005b), but with even less time spent resting at the surface after prey capture. During nonbreeding, Murphy's petrels spent much more time on the water, with reduced flight activity. Energy requirements are probably lower, yet during this period they also moult flight feathers which is an energetically demanding process. Indeed, recent studies have documented a quasi-flightless period associated with moult in many procellariids (Gutowsky et al. 2014, Cherel et al. 2016). Although very little is known about feather moult in Murphy's petrels, gadfly petrels perform a simple descendent moult, replacing primary feathers sequentially over a period of 3 to 4 mo (Bridge 2006). As Murphy's petrels decrease their flight activity substantially from November to February (Fig. 6), it is likely this period of relative inactivity coincides with moult (Cherel et al. 2016), supported by observations of fresh plumage on birds at sea in April and May (Howell 2012).

Whilst many gadfly petrels are known to be predominantly nocturnal (Brooke \& Prince 1991, Ramirez et al. 2013), the night-time activity of Murphy's petrels appears to be related to commuting rather than feeding behaviour, as during stages when birds travel shorter distances (pre-laying and non-breeding), they spent more time on the water at night. Although this could reflect a sit-and-wait foraging strategy seen in many albatrosses and larger petrels (e.g. Mackley et al. 2010), Murphy's petrels increase their flight activity at dawn, suggesting that they are predominantly crepuscular and diurnal rather than nocturnal foragers (contra Imber et al. 1995). The tracked birds consistently began to fly more in the hour or 2 before sunrise (except during incubation when their flight activity was always high), consistent with the hypothesis that they and other subtropical and tropical species rely heavily on nocturnally migrating prey, such as mesopelagic fish and squid (Ashmole 1971, Imber et al. 1995, Dias et al. 2012). Foraging by petrels is likely to be restricted by darkness, and morning twilight provides an optimal window when prey are still accessible and there is sufficient light for their visual detection.

\section{Implications for conservation}

It is clear that successful control or eradication of invasive mammals remains key to the recovery of seabird populations at Henderson and other islands in the Pacific Ocean (Brooke et al. 2010). The population of Murphy's petrels on Henderson is small compared to much larger populations on Ducie and Oeno in the same island group, and is thought to be maintained through immigration from Ducie, where rats have been eradicated (Brooke 1995). As there is probably little genetic differentiation between the 2 populations, the foraging behaviour of birds from Henderson might well match that of the other populations (Brooke 1995), but tracking of birds from other sites would be needed to confirm this.

Little is known about at-sea threats faced by Murphy's and other gadfly petrels (BirdLife International 2010); however, unlike many larger procellariiforms, Murphy's petrel is rarely recorded as bycatch in fisheries. The amount of time that petrels spend commuting to foraging areas during incubation trips suggests they might be at the limit of their energetic capabilities. As a result, birds may be susceptible to changes in the marine environment, such as the expansion of nutrient-poor areas in the South Pacific as a result of long-term increases in SSTs (Polovina et al. 2008). Whilst our study has identified important at-sea areas for Murphy's petrels that appear to vary little between years, site-based protection for this and other gadfly petrels with huge marine ranges would contribute rather less to their conservation than safeguarding and remediating their nesting habitats.

Acknowledgements. We are grateful to the Royal Society for the Protection of Birds (RSPB) and members of the Henderson Island Rat Eradication Project for logistical field support, to the Sir Peter Scott Commemorative Expedition to the Pitcairn Islands for geolocator purchase, and to Tom Churchyard and Tara Proud for retrieving loggers. We also thank Ana Bertoldi Carneiro for useful discussions, Jamie Oliver for help with the production of one of the figures, and 3 
anonymous reviewers whose comments improved the manuscript. T.A.C. was supported by a studentship funded as part of the Natural Environment Research Council (NERC) Standard Grant NE/J021083/1. This study represents a contribution to the Ecosystems component of the British Antarctic Survey Polar Science for Planet Earth Programme, funded by NERC.

\section{LITERATURE CITED}

Aarts G, MacKenzie M, McConnell B, Fedak M, Matthiopoulos J (2008) Estimating space-use and habitat preference from wildlife telemetry data. Ecography 31: 140-160

Afanasyev V (2004) A miniature daylight level and activity data recorder for tracking animals over long periods. Mem Natl Inst Polar Res 58:227-233

Arnold TW (2010) Uninformative parameters and model selection using Akaike's information criterion. J Wildl Manag 74:1175-1178

Ashmole NP (1971) Seabird ecology and the marine environment. In: Farner DS, King JR (eds) Avian biology, Vol 1. Academic Press, New York, NY, p 223-286

Au DWK, Pitman RL (1986) Seabird interactions with dolphins and tuna in the eastern tropical Pacific. Condor 88: 304-317

Bailey SF, Pyle P, Spear LB (1989) Dark Pterodroma petrels in the North Pacific: identification, status, and North American occurrence. Am Birds 43:400-415

Ballance LT, Pitman RL (1999) Foraging ecology of tropical seabirds. In: Adams NJ, Slotow RH (eds) Proc 22nd Int Ornithol Congr Durban. BirdLife South Africa, Johannesburg, p 2057-2071

Ballance LT, Pitman RL, Reilly SB (1997) Seabird community structure along a productivity gradient: importance of competition and energetic constraint. Ecology 78: 1502-1518

Bartle JA, Hu D, Stahl JC, Pyle P, Simons TR, Woodby D (1993) Status and ecology of gadfly petrels in the temperate North Pacific. In: Vermeer K, Briggs KT, Morgan KG, Siegel-Causey D (eds) The status, ecology, and conservation of marine birds of the North Pacific. Canadian Wildlife Service Special Publication, Ottawa, p 101-111

Bates D, Maechler M, Bolker B, Walker S and others (2015) $\mathrm{R}$ package lme4: linear mixed-effects models using 'eigen' and S4.

BirdLife International (2010) Threatened birds of the world. BirdLife International, Cambridge

Block BA, Jonsen ID, Jorgensen SJ, Winship AJ and others (2011) Tracking apex marine predator movements in a dynamic ocean. Nature 475:86-90

Bograd SJ, Foley DG, Schwing FB, Wilson C and others (2004) On the seasonal and interannual migrations of the transition zone chlorophyll front. Geophys Res Lett 31: L17204

Breed GA, Bowen WD, McMillan JI, Leonard ML (2006) Sexual segregation of seasonal foraging habitats in a non-migratory marine mammal. Proc Biol Sci 273: 2319-2326

Bridge ES (2006) Influences of morphology and behavior on wing-molt strategies in seabirds. Mar Ornithol 34:7-19

Brooke M (2004) Albatrosses and petrels across the world: Procellariiformes. Oxford University Press, Oxford
Brooke MdeL (1995) The breeding biology of the gadfly petrels Pterodroma spp. of the Pitcairn Islands: characteristics, population sizes and controls. Biol J Linn Soc 56: 213-231

Brooke MdeL, Prince PA (1991) Nocturnality in seabirds. In: Bell BD, Cossee RO, Flux JEC, Heather BD, Hitchmough RA, Robertson CJR, Williams MJ (eds) Acta XX Congressus Internationalis Ornithologici. New Zealand Ornithological Congress, Wellington, p 1113-1121

Brooke MdeL, O'Connell TC, Wingate D, Madeiros J, Hilton GM, Ratcliffe N (2010) Potential for rat predation to cause decline of the globally threatened Henderson petrel Pterodroma atrata: evidence from the field, stable isotopes and population modelling. Endang Species Res 11:47-59

Burnham KP, Anderson DR (2004) Model selection and multimodel inference: a practical information-theoretic approach. Springer Science + Business Media, New York, NY

Calenge C (2006) The package 'adehabitat' for the R software: A tool for the analysis of space and habitat use by animals. Ecol Model 197:516-519

Carneiro APB, Manica A, Clay TA, Silk JRD, King M, Phillips RA (2016) Consistency in migration strategies and habitat preferences of brown skuas over two winters, a decade apart. Mar Ecol Prog Ser 553:267-281

Catry T, Ramos JA, Le Corre M, Phillips RA (2009) Movements, at-sea distribution and behaviour of a tropical pelagic seabird: the wedge-tailed shearwater in the western Indian Ocean. Mar Ecol Prog Ser 391:231-242

Cherel Y, Quillfeldt P, Delord K, Weimerskirch H (2016) Combination of at-sea activity, geolocation and feather stable isotopes documents where and when seabirds moult. Front Ecol Evol 4:3

Claustre H, Maritorena S (2003) The many shades of ocean blue. Science 302:1514-1515

Clay TA, Manica A, Ryan PG, Silk JRD, Croxall JP, Ireland L, Phillips RA (2016) Proximate drivers of spatial segregation in non-breeding albatrosses. Sci Rep 6:29932

Congdon BC, Krockenberger AK, Smithers BV (2005) Dualforaging and co-ordinated provisioning in a tropical Procellariiform, the wedge-tailed shearwater. Mar Ecol Prog Ser 301:293-301

'D'Hondt S, Spivack AJ, Pockalny R, Ferdelman TG and others (2009) Subseafloor sedimentary life in the South Pacific Gyre. Proc Natl Acad Sci USA 106:11651-11656

Dandonneau Y, Deschamps PY, Nicolas JM, Loisel H and others (2004) Seasonal and interannual variability of ocean color and composition of phytoplankton communities in the North Atlantic, equatorial Pacific and South Pacific. Deep Sea Res II 51:303-318

Dias MP, Granadeiro JP, Phillips RA, Alonso H, Catry P (2011) Breaking the routine: individual Cory's shearwaters shift winter destinations between hemispheres and across ocean basins. Proc Biol Sci 278:1786-1793

Dias MP, Granadeiro JP, Catry P (2012) Working the day or the night shift? Foraging schedules of Cory's shearwaters vary according to marine habitat. Mar Ecol Prog Ser 467: $245-252$

* Dias MP, Romero J, Granadeiro JP, Catry T, Pollet IL, Catry P (2016) Distribution and at-sea activity of a nocturnal seabird, the Bulwer's petrel Bulweria bulwerii, during the incubation period. Deep Sea Res II 113:49-56

Dingle H (1996) Migration: the biology of life on the move, 1st edn. Oxford University Press, Oxford 
Fieberg J, Kochanny CO (2005) Quantifying home-range overlap: the importance of the utilization distribution. J Wildl Manag 69:1346-1359

Freeman E (2012) Package 'PresenceAbsence': presenceabsence model evaluation. Version 1.1.9. https://cran.rproject.org/web/packages/PresenceAbsence/index.html

Guilford T, Meade J, Willis J, Phillips RA and others (2009) Migration and stopover in a small pelagic seabird, the Manx shearwater Puffinus puffinus: insights from machine learning. Proc Biol Sci 276:1215-1223

*Gutowsky SE, Gutowsky LF, Jonsen ID, Leonard ML, Naughton MB, Romano MD, Shaffer SA (2014) Daily activity budgets reveal a quasi-flightless stage during non-breeding in Hawaiian albatrosses. Mov Ecol 2:23

Haney JC, Haury LR, Mullineaux LS, Fey CL (1995) Seabird aggregation at a deep North Pacific seamount. Mar Biol 123:1-9

Hays GC (2003) A review of the adaptive significance and ecosystem consequences of zooplankton diel vertical migrations. Hydrobiologia 503:163-170

Hedd A, Montevecchi WA, Otley H, Phillips RA, Fifield DA (2012) Trans-equatorial migration and habitat use by sooty shearwaters Puffinus griseus from the South Atlantic during the nonbreeding season. Mar Ecol Prog Ser 449: $277-290$

Hedd A, Montevecchi WA, Phillips RA, Fifield DA (2014) Seasonal sexual segregation by monomorphic sooty shearwaters Puffinus griseus reflects different reproductive roles during the pre-laying period. PLOS ONE 9: e85572

Hothorn T, Bretz F, Westfall P (2008) Simultaneous inference in general parametric models. Biom J 50:346-363

Howell SN (2012) Petrels, albatrosses, and storm-petrels of North America. Princeton University Press, Princeton, NJ

Hyrenbach KD, Fernandez P, Anderson DJ (2002) Oceanographic habitats of two sympatric North Pacific albatrosses during the breeding season. Mar Ecol Prog Ser 233:283-301

Hyrenbach KD, Veit RR, Weimerskirch H, Hunt GL Jr (2006) Seabird associations with mesoscale eddies: the subtropical Indian Ocean. Mar Ecol Prog Ser 324:271-279

Ichii T, Mahapatra K, Sakai M, Okada Y (2009) Life history of the neon flying squid: effect of the oceanographic regime in the North Pacific Ocean. Mar Ecol Prog Ser 378:1-11

Imber MJ, Jolly JN, Brooke MdeL (1995) Food of three sympatric gadfly petrels (Pterodroma spp.) breeding on the Pitcairn Islands. Biol J Linn Soc 56:233-240

IOC (Intergovernmental Oceanographic Commission) (2003) Centenary edition of the GEBCO digital atlas Intergovernmental Oceanographic Commission and the International Hydrographic Organization as part of the General Bathymetric Chart of the Oceans. British Oceanographic Data Centre, Liverpool

Jaquemet S, Corre ML, Marsac F, Potier M, Weimerskirch H (2005) Foraging habitats of the seabird community of Europa Island (Mozambique Channel). Mar Biol 147: 573-582

Jaquemet S, Ternon JF, Kaehler S, Thiebot JB and others (2014) Contrasted structuring effects of mesoscale features on the seabird community in the Mozambique Channel. Deep Sea Res II 100:200-211

Kappes MA, Shaffer SA, Tremblay Y, Foley DG and others (2010) Hawaiian albatrosses track interannual variability of marine habitats in the North Pacific. Prog Oceanogr
$86: 246-260$

Le Corre M, Jaeger A, Pinet P, Kappes MA and others (2012) Tracking seabirds to identify potential marine protected areas in the tropical western Indian Ocean. Biol Conserv 156:83-93

Longhurst AR (2007) Ecological geography of the sea. Academic Press, Burlington, MA

Longhurst AR, Pauly D (1987) Ecology of tropical oceans. Academic Press, San Diego, CA

"Mackley EK, Phillips RA, Silk JRD, Wakefield ED, Afanasyev V, Fox JW, Furness RW (2010) Free as a bird? Activity patterns of albatrosses during the nonbreeding period. Mar Ecol Prog Ser 406:291-303

MacLeod CJ, Adams J, Lyver P (2008) At-sea distribution of satellite-tracked grey-faced petrels, Pterodroma macroptera gouldi, captured on the Ruamaahua (Aldermen) Islands, New Zealand. Pap Proc R Soc Tasman 142:73-88

Mannocci L, Catalogna M, Dorémus G, Laran S and others (2014) Predicting cetacean and seabird habitats across a productivity gradient in the South Pacific gyre. Prog Oceanogr 120:383-398

Navarro J, Votier SC, Aguzzi J, Chiesa JJ, Forero MG, Phillips RA (2013) Ecological segregation in space, time and trophic niche of sympatric planktivorous petrels. PLOS ONE 8:e62897

Nicoll MAC, Nevoux M, Jones CG, Ratcliffe N, Ruhomaun K, Tatayah V, Norris K (2017) Contrasting effects of tropical cyclones on the annual survival of a pelagic seabird in the Indian Ocean. Glob Change Biol 23:550-565

Nychka D, Furrer R, Paige J, Sain S (2016) R package 'fields': tools for spatial data. Version 9.0. https://cran.rproject.org/web/packages/fields/index.html

*Péron C, Delord K, Phillips RA, Charbonnier Y, Marteau C, Louzao M, Weimerskirch H (2010) Seasonal variation in oceanographic habitat and behaviour of white-chinned petrels Procellaria aequinoctialis from Kerguelen Island. Mar Ecol Prog Ser 416:267-284

Phillips RA, Xavier JC, Croxall JP (2003) Effects of satellite transmitters on albatrosses and petrels. Auk 120: 1082-1090

Phillips RA, Silk JRD, Croxall JP, Afanasyev V, Briggs DR (2004a) Accuracy of geolocation estimates for flying seabirds. Mar Ecol Prog Ser 266:265-272

*Phillips RA, Silk JRD, Phalan B, Catry P, Croxall JP (2004b) Seasonal sexual segregation in two Thalassarche albatross species: Competitive exclusion, reproductive role specialization or foraging niche divergence? Proc Biol Sci 271:1283-1291

*Phillips RA, Silk JRD, Croxall JP, Afanasyev V, Bennett VJ (2005) Summer distribution and migration of nonbreeding albatrosses: individual consistencies and implications for conservation. Ecology 86:2386-2396

Phillips RA, McGill RAR, Dawson DA, Bearhop S (2011) Sexual segregation in distribution, diet and trophic level of seabirds: insights from stable isotope analysis. Mar Biol 158:2199-2208

Pinet $\mathrm{P}$, Jaquemet $\mathrm{S}$, Pinaud D, Weimerskirch H, Phillips RA, Le Corre M (2011) Migration, wintering distribution and habitat use of an endangered tropical seabird, Barau's petrel Pterodroma baraui. Mar Ecol Prog Ser 423: 291-302

* Pinet P, Jaquemet S, Phillips RA, Le Corre M (2012) Sex-specific foraging strategies throughout the breeding season in a tropical, sexually monomorphic small petrel. Anim Behav 83:979-989 
Pollet IL, Ronconi RA, Jonsen ID, Leonard ML, Taylor PD, Shutler D (2014) Foraging movements of Leach's stormpetrels Oceanodroma leucorhoa during incubation. J Avian Biol 45:305-314

Polovina JJ, Howell E, Kobayashi DR, Seki MP (2001) The transition zone chlorophyll front, a dynamic global feature defining migration and forage habitat for marine resources. Prog Oceanogr 49:469-483

*Polovina JJ, Howell EA, Abecassis M (2008) Ocean's least productive waters are expanding. Geophys Res Lett 35: L03618

Priddel D, Carlile N, Portelli D, Kim Y and others (2014) Pelagic distribution of Gould's petrel (Pterodroma leucoptera): linking shipboard and onshore observations with remote-tracking data. Emu 114:360-370

Quillfeldt P, Phillips RA, Marx M, Masello JF (2014) Colony attendance and at-sea distribution of thin-billed prions during the early breeding season. J Avian Biol 45: 315-324

R Core Team (2014) R: a language and environment for statistical computing. R Foundation for Statistical Computing, Vienna

Ramirez I, Paiva VH, Menezes D, Silva I, Phillips RA, Ramos JA, Garthe S (2013) Year-round distribution and habitat preferences of the Bugio petrel. Mar Ecol Prog Ser 476: 269-284

* Ramos R, Ramírez I, Paiva VH, Militão T and others (2016) Global spatial ecology of three closely-related gadfly petrels. Sci Rep 6:23447

Rayner MJ, Hauber ME, Clout MN, Seldon DS, Van Dijken S, Bury S, Phillips RA (2008) Foraging ecology of the Cook's petrel Pterodroma cookii during the austral breeding season: a comparison of its two populations. Mar Ecol Prog Ser 370:271-284

Rayner MJ, Hauber ME, Steeves TE, Lawrence HA and others (2011) Contemporary and historical separation of transequatorial migration between genetically distinct seabird populations. Nat Commun 2:332

Rayner MJ, Taylor GA, Gummer HD, Phillips RA, Sagar PM, Shaffer SA, Thompson DR (2012) The breeding cycle, year-round distribution and activity patterns of the endangered Chatham petrel (Pterodroma axillaris). Emu 112:107-116

Rayner MJ, Carlile N, Priddel D, Bretagnolle V and others (2016) Niche partitioning by three Pterodroma petrel species during non-breeding in the equatorial Pacific Ocean. Mar Ecol Prog Ser 549:217-229

Regular PM, Davoren GK, Hedd A, Montevecchi WA (2010) Crepuscular foraging by a pursuit-diving seabird: tactics of common murres in response to the diel vertical migration of capelin. Mar Ecol Prog Ser 415:295-304

Roberts JJ, Best BD, Dunn DC, Treml EA, Halpin PN (2010) Marine geospatial ecology tools: an integrated framework for ecological geoprocessing with ArcGIS, Python, R, MATLAB, and C++. Environ Model Softw 25: 1197-1207

Robinson PW, Costa DP, Crocker DE, Gallo-Reynoso JP and others (2012) Foraging behavior and success of a mesopelagic predator in the northeast Pacific Ocean: insights

Editorial responsibility: Rory Wilson, Swansea, UK from a data-rich species, the northern elephant seal. PLOS ONE 7:e36728

Saba VS, Shillinger GL, Swithenbank AM, Block BA, Spotila JR, Musick JA, Paladino FV (2008) An oceanographic context for the foraging ecology of eastern Pacific leatherback turtles: consequences of ENSO. Deep Sea Res I 55:646-660

Shaffer SA, Weimerskirch H, Costa DP (2001) Functional significance of sexual dimorphism in wandering albatrosses, Diomedea exulans. Funct Ecol 15:203-210

Shaffer SA, Tremblay Y, Weimerskirch H, Scott D and others (2006) Migratory shearwaters integrate oceanic resources across the Pacific Ocean in an endless summer. Proc Natl Acad Sci USA 103:12799-12802

Shillinger GL, Swithenbank AM, Bailey H, Bograd SJ and others (2011) Vertical and horizontal habitat preferences of post-nesting leatherback turtles in the South Pacific Ocean. Mar Ecol Prog Ser 422:275-289

Spear LB, Ainley DG (1998) Morphological differences relative to ecological segregation in petrels (Family: Procellariidae) of the Southern Ocean and tropical Pacific. Auk 115:1017-1033

Spear LB, Ainley DG, Walker WA (2007) Foraging dynamics of seabirds in the eastern tropical Pacific Ocean. Stud Avian Biol 35:1-99

Springer AM, Piatt JF, Shuntov VP, Van Vliet GB Vladimirov VL, Kuzin AE, Perlov AS (1999) Marine birds and mammals of the Pacific Subarctic Gyres. Prog Oceanogr 43:443-487

Steadman DW, Olson SL (1985) Bird remains from an archaeological site on Henderson Island, South Pacific: man-caused extinctions on an 'uninhabited' island. Proc Natl Acad Sci USA 82:6191-6195

Torr N, Brown D (2012) Henderson Island restoration project post operational report. Royal Society for the Protection of Birds, Sandy

Warham J (1990) The petrels: their ecology and breeding systems. Academic Press, San Diego, CA

Watanabe H, Kubodera T, Ichii T, Kawahara S (2004) Feeding habits of neon flying squid Ommastrephes bartramii in the transitional region of the central North Pacific. Mar Ecol Prog Ser 266:173-184

Weimerskirch H (2007) Are seabirds foraging for unpredictable resources? Deep Sea Res II 54:211-223

Weimerskirch $\mathrm{H}$, Le Corre $\mathrm{M}$, Ropert-Coudert $\mathrm{Y}$, Kato A, Marsac F (2005a) The three-dimensional flight of redfooted boobies: Adaptations to foraging in a tropical environment? Proc Biol Sci 272:53-61

Weimerskirch H, Gault A, Cherel Y (2005b) Prey distribution and patchiness: factors in foraging success and efficiency of wandering albatrosses. Ecology 86:2611-2622

Wood S (2006) Generalized additive models: an introduction with R. CRC Press, Boca Raton, FL

Y Yesson C, Clark MR, Taylor ML, Rogers AD (2011) The global distribution of seamounts based on 30 arc seconds bathymetry data. Deep Sea Res I 58:442-453

Žydelis R, Lewison RL, Shaffer SA, Moore JE and others (2011) Dynamic habitat models: using telemetry data to project fisheries bycatch. Proc Biol Sci 278:3191-3200

Submitted: July 25, 2016; Accepted: June 30, 2017

Proofs received from author(s): September 8, 2017 